\title{
KAJIAN SEMIOTIK KUMPULAN PUISI TERSEBAB AKU MELAYU KARYA TAUFIK IKRAM JAMIL
}

\author{
Meiranisah Arkha ${ }^{1}$, Elmustian $^{2}$, Hadi Rumadi ${ }^{3}$ \\ Universitas Riau, Pekanbaru, Indonesia ${ }^{1},{ }^{2}, 3$ \\ meiranisaharkha@gmail.com ${ }^{1}$,elmustian@yahoo.com ${ }^{2}$,hadirumadipbsi@gmail.com ${ }^{3}$
}

\begin{abstract}
Semiotics is a method of analysis that examines signs. This collection of poems Tersebab Aku Melayu by Taufik Ikram Jamil works contains many semiotic elements such as icons, indexes, and symbols. This study only focused on 14 poems from 59 poetry collections Tersebab Aku Melayu by Taufik Ikram Jamil. In this study, three problem formulas examine semiotics, namely what are the icons contained in a collection of poetry Tersebab Aku Melayu by Taufik Ikram Jamil, what are the indices contained in a collection of poetry Tersebab Aku Melayu by Taufik Ikram Jamil, and what are the symbols contained in a collection of poetry Tersebab Aku Melayu by Taufik Ikram Jamil. This study aims to describe the semiotic collection of poetry Tersebab Aku Melayu by Taufik Ikram Jamil. The benefit of this research is to increase the reader's understanding and knowledge about literature, especially on the semiotic study contained poetry Tersebab Aku Melayu by Taufik Ikram Jamil. The theory used in this research is semiotic studies which include aspects of icons, index aspects, and aspects of the symbol. The research data that the writer took in the form of words in the form of phrases, clauses, and sentences in the text contained in a collection of poetry books. The technique of collecting data in this research is a literature study. While the analysis technique used is reducing data, presenting the data and drawing the conclusion. The data of this study amounted to 314, consisting of 14 poems. Each character experienced their stages of existence of the religious stage. The details of 314 data are as follow, in the aspect of the icon found 1n 274 data, the index aspect was found in 12 data, and the aspect symbol was found in 28 data.
\end{abstract}

Keywords: Semiotics, icons, indexes, symbols, poetry

\begin{abstract}
ABSTRAK
Semiotik adalah metode analisis yang mengkaji tentang tanda. Kumpulan puisi Tersebab Aku Melayu Karya Taufik Ikram Jamil ini banyak mengandung unsur semiotika seperti ikon, indeks, dan simbol. Penelitian ini hanya memfokuskan 14 puisi dari 59 kumpulan puisi Tersebab Aku Melayu Karya Taufik Ikram Jamil. Rumusan masalah dalam penelitian ini yaitu apa saja semiotika yang terdapat dalam kumpulan puisi Tersebab Aku Melayu Karya Taufik Ikram Jamil. Penelitian ini bertujuan untuk mendeskripsikan semiotika kumpulan puisi Tersebab Aku Melayu Karya Taufik Ikram Jamil. Manfaat dari penelitian ini untuk menambah pemahaman dan pengetahuan pembaca mengenai sastra khususnya pada kajian semiotik yang terdapat dalam kumpulan puisi Tersebab Aku Melayu Karya Taufik Ikram Jamil. Teori yang digunakan dalam penelitian ini adalah teori tentang kajian semiotik yang meliputi aspek ikon, aspek indeks, dan aspek simbol. Data penelitian yang penulis ambil berupa kata berbentuk frase, klausa, dan kalimat dalam teks yang ada dalam buku kumpulan puisi Tersebab Aku Melayu karya Tufik Ikram Jamil. Teknis pengumpulan data dalam penelitian ini adalah studi pustaka. Teknis analisis yang digunakan adalah mereduksi data,
\end{abstract}


penyajian data dan penarikan kesimpulan akhir. Hasil penelitian menunjukan bahwa karya Taufik Ikram Jamil banyak terdapat semiotika, dan data penelitian yang lebih dominan adalah semiotika aspek ikon. Data keseluruhan penelitian ini berjumlah 314 yang terdiri dari 14 puisi.

Kata Kunci: Semiotik, ikon, indeks, simbol, puis

\section{PENDAHULUAN}

Semiotik merupakan struktur tanda yang bermakna. Suatu karya sastra tidak akan bisa dimengerti apabila tidak memahami bentuk dari tanda itu sendiri. Semiotik merupakan penelaahan ilmu tanda yang begitu luas. Semiotik digunakan untuk memecahkan dengan lebih baik masalah signifikasi komunikasi yang berkaitan dengan pesan yang akan disampaikan kepada penikmat satra ataupun pendengar. Menurut Hoed (2011:3), "Semiotik adalah ilmu yang mengkaji tanda dalam kehidupan manusia." Artinya semua yang hadir dalam kehidupan harus dilihat sebagai tanda, yaitu sesuatu yang harus diberikan makna. Akan tetapi tidak semua dapat dikaji secara semiotik, katena semiotik hanya mengkaji sesuatu yang tidak wajar. Puisi menggunakan bahasa sebagai media untuk mengungkapkan imajinasi serta emosi pengarang. Keseluruhan ekspresi yang terdapat dalam puisi yang secara langsung dapat melibatkan kajian semiotik. Menganalisis puisi menggunakan kajian semiotik, berarti mengungkap tanda dan akan memahami makna yang terdapat dalam puisi. Karya sastra mengandung unsur kebenaran serta keberanian untuk menampilkannya. Karya sastra adalah hasil olah pikir manusia terhadap sesuatu keadaan yang telah terjadi dan akan terjadi. (Supriya, dkk: 2020)

Semiotika adalah ilmu yang mempelajari tanda (sign), berfungsinya tanda dan produksi makna. Tanda adalah sesuatu yang bagi seseorang berarti sesuatu dengan yang lainnya. Dalam pandangan Zoes, segala sesuatu yang dapat diamati atau dibuat teramati dapat disebut tanda.Karena itu, tanda tidaklah terbatas pada benda. A. Teew (1984:6), mendefinisikan semiotik adalah tanda sebagai tindakan komunikasi dan kemudian disempurnakan menjadi model sastra yang mempertanggungjawabkan semua faktor dan aspek hakiki, untuk pemahaman gejala susastra sebagai alat komunikasi yang khas dalam masyarakat. Karya sastra merupakan hasil pekerjaan seni kreatif dari pengarangnya. Hasil karangan tersebut dapat dihasilkan dalam berberapa bentuk yaitu, puisi, prosa dan juga drama.

Menurut Tarigan (1985:8), mengatakan bahwa sastra merupakan objek bagi pengarang untuk mengungkapkan gejolak emosinya, misalnya perasaan sedih kecewa, senang, dan lain sebagainya. Sedangkan menurut Jan van Lexemburg (dalam Elmustian, 2004:24), mendefenisikan ilmu sastra sebagai ilmu sastra umum, yaitu sebuah telaah sistematis mengenai sastra: sistem kaidah, modul-modul, sifat-sifat, fungsi dan komunikasi sastra yang pada prinsipnya tidak menghiraukan batas-batas antar bangsa dan antar kebudayaan.

Melalui semiotik kita bisa menganalisis teks, bahasa, media dan gerak tubuh. Dengan mengkaji semiotika, akan mengungkapkan asumsi dasar dari sebuah karya sastra itu sendiri. Asumsi mengenai makna yang tersirat dalam suatu karya sastra yang memandang melalui penandaanya.

Sumardjo \& Saini (1997: 3-4), menyatakan bahwa sastra adalah ungkapan pribadi manusia yang berupa pengalaman, pemikiran, perasaan, ide, semangat, keyakinan dalam suatu bentuk gambaran konkret yang membangkitkan pesona dengan alat bahasa. Sehingga sastra memiliki unsur-unsur berupa pikiran, pengalaman, ide, perasaan, semangat, kepercayaan (keyakinan), ekspresi atau ungkapan, bentuk dan bahasa.

Sehingga dapat dipahami bahwasannya semiotik merupakan bahasa yang mencerminkan bahasa sastra yang estetis, sistematis dan memiliki pluralitas makna ketika dibaca oleh pembaca dalam memberi pemahaman terhadap teks karya sastra. Bahasa yang penuh makna dalam sebuah karya sastra baru dapat dipahami jika tanda-tanda yang dituliskan oleh pengarang ditangkap secara utuh oleh pembaca

Penulis mengambil kumpulan puisi karya Taufik Ikram Jamil sebagai objek penelitian, 
karena penulis ingin menafsirkan makna yang terdapat dalam puisi pada sastrawan Melayu Riau, sebagai bentuk apresiasi terhadap sastrawan Riau yang nantinya juga bertujuan untuk memperkenalkan puisi dalam kumpulan puisi itu sendiri.

Suatu karya sastra tidak akan bisa dimengerti apabila tidak memahami bentuk dari tanda itu sendiri. Semiotik merupakan penelaahan ilmu tanda yang begitu luas, dan digunakan untuk memecahkan dengan lebih baik masalah signifikasi komunikasi yang berkaitan dengan pesan yang akan disampaikan kepada penikmat satra ataupun pendengar. Untuk menganalisis sistem tanda yang terdapat dalam puisi dapat menggunakan kajian semiotik yang dapat mengungkap tanda dan memahami makna dari puisi. Jenis-jenis tanda yang utama adalah ikon, indeks dan symbol.

Ikon adalah suatu benda yang secara fisik yang menyerupai apa yang direpresentasikannya. Representasi yang dimaksudkan merupakan, adanya kemiripan dari benda yang dimaksud. Misalnya, foto Ir. Soekarno merupakan ikon dari Ir. Soekarno. Maksudnya disini adalah, foto tersebut merupakan representasi langsung dari Ir. Soekarno, dimana adanya gambaran secara menyeluruh dari bentuk fisik Ir. Soekarno.

Menurut Pradopo (dalam Imerisna, 2013:16) Ikon adalah tanda hubungan antara penanda dan petandanya yang bersifat alamiah, contohnya potret orang menandai orang yang ada dipotret, gambar kuda menandai kuda yang nyata. Ikon merupakan tanda, yang secara inheren memiliki kesamaan dengan arti yang ditunjuk. Misalnya, foto dengan orang yang difoto atau peta dengan geografisnya.

Menurut Pradopo (2009:121), Indeks adalah tanda yang menunjukkan ada hubungan alamiah antara tanda dan petanda yang berhubungan sebab akibat antara penanda dan petandanya.

Indeks adalah tanda yang hadir dengan cara saling terhubung akibat terdapatnya hubungan ciri acuan yang sifatnya tetap. Kata rokok, misalnya, memiliki indeks asap. Hubungan indeksikal antara rokok dengan asap terjadi karena terdapatnya hubungan ciri yang bersifat tetap antara 'rokok' dengan 'asap'. Ciri tersebut antara yang satu dengan yang lain berbeda dan tidak dapat saling menggantikan. Ciri utama pada rokok, misalnya, berbeda dengan asap (Sobur, 2003:159).

Dari penjelasan di atas, indeks adalah tanda yang mengacu pada kenyataan. Indeks merupakan tanda yang dengan acuannya mempunyai kedekatan eksistensi (sebab-akibat). Misalnya, hari mendung merupakan tanda akan hujan. Selanjutnya,

Menurut Pradopo (2009:121) Simbol adalah tanda yang menunjukkan bahwa tidak ada hubungan alamiah antara penanda dan petandanya, hubungan bersifat arbitrer (Semaumaunya) hubungan berdasarkan konvensi (perjanjian) masyarakat. Istilah simbol juga dapat diartikan sebagai lambang yang mengacu kepada objek tertentu diluar lambang itu.

Hubungan di antaranya bersifat arbitrer atau semena, atau hubungan berdasarkan konvensi (perjanjian masyarakat). Simbol adalah bentuk yang menandai sesuatu yang lain di luar bentuk perwujudan bentuk simbolik itu sendiri.

Zaimar (2008:168) simbol adalah tanda yang paling canggih karena sudah berdasarkan persetujuan dalam masyarakat (konvensi). Contohnya kode simpul tali pramuka merupakan simbol, rambu-rambu lalu lintas juga termasuk kedalam simbol.

Dari penjelasan tersebut, symbol adalah tanda yang memiliki hubungan makna dengan yang ditandakan bersifat arbitrer, sesuai dengan konvensi dan kesepakatan suatu lingkungan social tertentu. Misalnya, bendera putih dapat disimbolkan sebagai adanya kematian.

\section{METODOLOGI PENELITIAN}

Penelitian ini menggunakan pendekatan kualitatif deskriptif. Metode yang digunakan dalam penelitian ini adalah analisis semiotik yang merupakan cara atau metode untuk menganalisis dan menentukan ikon, indeks dan simbol dari kumpulan puisi Tersebab Aku Melayu Karya Taufik Ikram Jamil. Setelah data dikumpulkan, dilakukan beberapa tahapan. Tahapan-tahapan tersebut sebagai berikut:

1. Mengidentifikasi kata dan kalimat yang mengandung ikon, indeks dan simbol yang terdapat dalam kumpulan puisi Tersebab Aku Melayu. 
2. Memeriksa kualitas data dengan membaca secara cermat dan berulang-ulang apakah terdapat tanda-tanda pada data yang sudah dikumpulkan.

3. Mengklasifikasikan data, yaitu mengelompokkan data ikon, indeks dan simbol yang terdapat dalam kumpulan puisi Tersebab Aku Melayu.

4. Memaparkan data yaitu mendeskripsikan ikon, indeks dan simbol yang terdapat dalam kumpulan puisi Tersebab $A k u$ Melayu.

5. Membuat kesimpulan hasil analisis data ikon, indeks dan simbol yang terdapat dalam kumpulan puisi Tersebab Aku Melayu.

Penyajian data dilakukan berdasarkan fakta yang tampak sebagaimana adanya. Pada dasarnya, deskripsi merupakan gaya penelitian yang bersifat menggambarkan secara rinci mengenai objek yang dideskripsikan.

Sumber data yang digunakan dalam penelitian ini adalah sumber data teks puisi dalam buku kumpulan puisi Tersebab Aku Melayu Karya Taufik Ikram Jamil. Teknik pengumpulan data pada penelitian ini menggunakan teknik dokumentasi (buku kupulan puisi Tersebab Aku Melayu), teknik baca dan memahami, dan teknik menandai.

Data penelitian yang digunakan penulis dalam penelitian ini adalah kualitatif yang berupa kata berbentuk frase, kalausa, dan kalimat dalam teks yang ada dalam buku kumpulan puisi Tersebab Aku Melayu karya Tufik Ikram Jamil. Terdapat 59 puisi didalam kumpulan puisi tersebut.

\section{HASIL DAN PEMBAHASAN}

Hasil penelitian ini menentukan dan menjelaskan ikon, indeks, dan simbol yang terdapat dalam kumpulan puisi Tersebab Aku Melayu karya Taufik Ikram Jamil.

\section{Analisis Semiotik Aspek Ikon}

Menurut Pradopo (dalam Imerisna, 2013:16) Ikon adalah tanda hubungan antara penanda dan petandanya yang bersifat alamiah, contohnya potret orang menandai orang yang ada dipotret, gambar kuda menandai kuda yang nyata.
1) Gurindam Bukit Siguntung

Kupandang dikau dalam sebuah petang

Cuma aku bukan demang lebar daun

Tak aku wan sundari

Pun tak wan empuk wan malini aku

(Jamil, 2010:1)

Data di atas merupakan ikon dari kumpulan puisi Tersebab Aku Melayu. Data pada kata "ku" adalah sebagai penanda yang mewakili ungkapan dari penyair puisi tersebut. Kata aku yaitu kata ganti orang pertama tunggal yang merupakan gambaran langsung ikon dari petanda. Data tersebut menjelaskan perasaan penyair tentang peristiwa yang telah ia alami.

Sedangkan data pada kata "dikau" merupakan kata lain dari engkau yang merupakan pada puisi karya Taupik Ikram Jamil. Data tersebut memiliki hubungan dengan orang yang dibicarakan dalam objek puisi tersebut.

2) Hanya karena Aku Bukan Seorang Jawa Biografi Dara Petak

Inilah tahun-tahunku menjadi sehamparan cemas

Dan cinta yang kuhembus dari nafas paya

Hanya karena aku bukan seorang jawa

Kuajarkan kertarajasa jayawardhana

(Jamil, 2010:4)

Data di atas merupakan ikon dari kumpulan puisi Tersebab Aku Melayu. Data pada kata "ku, aku" merupakan ikon pada puisi karya Taufik Ikram Jamil. Makna pada puisi tersebut yang menyatakan orang pertama sebagai objek dari puisi yang ingin disampaikan.

3) Inilah Tabikku yang Ditangkap Senyap

Maka berlabuhlah suara-suara dari negeri jauh

Ketika hidup mengenalnya sebagai teman (Jamil, 2010:10)

Data di atas merupakan ikon dari kumpulan puisi Tersebab Aku Melayu. Data di atas merupakan penanda yang terdapat pada kata "negeri". Penulis menggunakan kata "negeri" sebagai hubungan gambaran mengenai negaranegara yang ada di Indonesia.

Data pada kata "teman" yang artinya tentang seseorang yang menjalin hubungan satu dengan yang lainnya. Kata "teman" merupakan makna yang diwakilinya dalam puisi tersebut.

4) Tak sempat pulang ke Riau 
Megat sri rama tak sempat pulang ke riau

Setelah perut isterinya dibelah percuma

(Jamil, 2010:13)

Data di atas merupakan ikon dari kumpulan puisi Tersebab Aku Melayu. Kata "Riau" merupakan hubungan gambaran sebuah wilayah yang sudah lama tidak dikunjungi oleh seseorang. Kemudian data pada kata "nya" dan "dia" merupakan penanda orang yang dibicarakan penulis dalam puisi tersebut yang merupakan kata ganti orang ketiga, dan orang ketiga jamak.

5) Catatan terakhir oleh Raffles

Kembali teringat Singapura dari suatu tempat

(Jamil, 2010:15)

Data di atas merupakan ikon dari kumpulan puisi Tersebab Aku Melayu. Data yang tedapat pada kata "Singapura" merupakan ikon dalam puisi tersebut. Singapura adalah penanda untuk menyatakan tempat pada suatu kota yang berkaitan dengan makna dari puisi.

\section{Analisis Semiotik Aspek Indeks}

Menurut Pradopo (2009:121) Indeks adalah tanda yang menunjukkan ada hubungan alamiah antara tanda dan petanda yang berhubungan sebab akibat antara penanda dan petandanya.

1) Gurindam Bukit Siguntung

\section{Ketika tubuh mu kian menunduk}

Karena beban sejarah sejuk berpeluk

(Jamil, 2010:1)

Data di atas merupakan indeks dari kumpulan puisi Tersebab Aku Melayu. Data pada "Ketika tubuh mu kian menunduk" merupakan sebab yang terjadinya sesuatu sebagai ungkapan penulis tentang banyaknya masalah yang telah ia alami. Data pada "karena beban sejarah sejuk berpeluk" merupakan akibat dari sebab yang merupakan ungkapan penulis tentang beban yang ada di dalam hidupnya dan mengakibatkan ia menyerah serta pasrah dengan keadaan.

Hal ini menunjukkan hubungan antara penanda "ketika tubuh mu kian menunduk" sebagai sebab kepasrahannya dalam menghadapi masalah hidup. Kalimat "karena beban sejarah sejuk berpeluk" yang merupakan akibat dari kepasrahannya.

2) Hanya karena Aku Bukan Seorang Jawa Biografi Dara Petak
Oleh hasat dengki yang ditinggalkan budi

Hanya karena aku bukan seorang jawa

(Jamil, 2010:4)

Data di aas merupakan indeks dari kumpulan puisi Tersebab Aku Melayu. Data pada kalimat "oleh hasat dengki yang ditinggalkan budi" merupakan sebab yang diungkapkan penulis tentang kebaikan seseorang yang tidak dipandang akibat rasa dengki. Kalimat "hanya karena aku bukan seorang jawa" adalah akibat dari sebab yang merupakan ungkapan penulis tentang kebaikan yang tidak dianggap dikarenakan si aku bukan orang Jawa.

3) Inilah Tabikku yang Ditangkap senyap

Tapi biarkanlah kuhafal komat-kamit bibirmu Agar dalam gerak pun aku tidak terkucil

(Jamil, 2010:11)

Data di atas merupakan indeks dari kumpulan puisi Tersebab Aku Melayu. Data pada kalimat "tapi biarkanlah kuhafal komat-kamit bibirmu" ialah sebab yang diungkapkan oleh penulis tentang rasa cinta yang selalu memperhatikan dan ingin mendengarkan curhatan dari pasangannya. Data pada kalimat "agar dalam gerak pun aku tidak terkucil" ialah akibat dari sebab yang merupakan ungkapan penulis tentang seseorang yang selalu ingin tahu tentang kepribadian kekasihnya.

4) Tak Sempt Pulang ke Riau

Megat Sri Rama tak sempat pulang ke Riau

Sebab ajal menunggunya di kota terbilang

(Jamil, 2010:13)

Data di atas merupakan indeks dari kumpulan puisi Tersebab Aku Melayu. Data pada kalimat "Megat Sri Rama tak sempat pulang ke Riau" ialah sebab yang diungkapkan penulis tentang seseorang yang ingin pulang ke Riau. Kalimat pada kata "sebab ajal menunggunya di kota terbilang" ialah akibat dari sebab yang merupakan ungkapan penulis tentang seseorang yang telah meninggal namun keinginannya pulang ke Riau tidak tercapai.

5) Catatan Terakhir oleh Raffles

Pada suatu ruang yang malahan tak terjangkau sunyi

Aku merasa ingin pergi

(Jamil, 2010:15)

Data di atas merupakan indeks dari kumpulan puisi Tersebab Aku Melayu. Data pada kalimat "Pada suatu ruang yang malahan tak 
terjangkau sunyi" ialah sebab yang diungkapkan oleh penulis mengenai suatu tempat keramaian yang jauh dari kata sepi. Kalimat pada kata "aku merasa ingin pergi" ialah akibat dari sebabyang diungkapkan penulis tentang si aku yang ingin pergi dari tempat keramaian.

\section{Analisis Semiotik Aspek Simbol}

Menurut Pradopo (2009:121) Simbol adalah tanda yang menunjukkan bahwa tidak ada hubungan alamiah antara penanda dan petandanya, hubungan bersifat arbitrer (Semaumaunya) hubungan berdasarkan konvensi (perjanjian) masyarakat. Istilah simbol juga dapat diartikan sebagai lambang yang mengacu kepada objek tertentu diluar lambang itu.

1) Gurindam Bukit Siguntung

\section{Ketika tubuh mu kian menunduk}

Dimamah usia terus melapuk

(Jamil, 2010:1)

Data di atas merupakan simbol dari kumpulan puisi Tersebab Aku Melayu. Data pada kalimat "menunduk" ialah yang menandai tentang tubuh yang akan semakin bungkuk apabila umur semakin tua. Setiap manusia akan mengalami tubuh yang semakin bungkuk jika menginjak lanjut usia dan tenaga dan kekuatan tubuh mulai berkurang. Data pada kalimat "melapuk" yang menandakan usia yang setiap tahunnya akan bertambah dan tubuh akan terus menjadi tua.

2) Hanya karena Aku Bukan Seorang Jawa Biografi Dara Petak

\section{Sunyi pada kicauan burung}

Papan diinjak tidak akan jungkit

(Jamil, 2010:4)

Data di atas merupakan simbol dari kumpulan puisi Tersebab Aku Melayu. Data pada kalimat "Sunyi pada kicauan burung" merupakan simbol yang menandai tentang rasa sunyi yang dialami padahal sedang berada dalam keramaian. Ia merasakan kehampaan dalam hidupnya meskipun sedang berada dalam keamaian.

Data pada kalimat "papan diinjak tidak akan jungkit" ialah simbol yang menandai tentang seseorang yang jika dihina atau dimaki ia tidak akan mudah menyerah dalam melakukan kebaikan. Kemulian hati berkat didikan orang tualah yang membuat seseorang tumbuh menjadi manusia yang kuat dalam menghadapi masalah hidup.

3) Inilah Tabikku yang Ditangkap Senyap

Di mulutmu teduh

Sejuk kalimat

(Jamil, 2010:10)

Data di atas merupakan simbol dari kumpulan puisi Tersebab Aku Melayu. Data pada kalimat "di mulutmu teduh" adalah simbol yang menandai perkataan seorang yang lemah lembut ucapannya. Maka orang lain akan merasa nyaman mendengar perkataan orang tersebut jika berbicara, karena perkataannya tidak pernah menyakiti hati orang lain. Data pada kalimat "Sejuk kalimat" adalah simbol tanda bukti perkataan yang lemah lembut, dan sopan dalam berbicara serta membuat orang senang mendengar perkataannya.

4) Tak Sempat Pulang ke Riau

\section{Janin perkasa}

(Jamil, 2010:13)

Data di atas merupakan simbol dari kumpulan puisi Tersebab Aku Melayu. Data pada kalimat "janin perkasa" ialah simbol yang menandai tentang calon anak yang kuat yang dimaksud dalam puisi tersebut. kalimat tersebut merupakan simbol yang menandai anak yang kuat serta bijaksana dalam memimpin jika ia kelak menjadi seorang pemimpin.

5) Catatan Terakhir oleh Raffles

Rumah adalah sorga

(Jamil, 2010:17)

Data di atas merupakan simbol dari kumpulan puisi Tersebab Aku Melayu. Simbol dalam puisi yang berjudul Data pada kalimat "rumah adalah sorga" ialah simbol yang menandai tentang keluarga yang memiliki kebahagian serta hidup rukun damai. kalimat tersebut merupakan simbol yang menandai bahwa keluarga merupakan harta yang paling berharga serta menjadi tempat berlindung yang nyaman dan indah.

\section{Semiotik Aspek Ikon}

Berdasarkan hasil penelitian yang telah dilakukan, maka Ikon merupakan bentuk fisik yang menyerupai dari benda itu sendiri. Ikon merupakan tanda yang memiliki hubungan antara penanda dan petandanya yang bersifat bersamaan bentuk ilmiah dan fisik. Menurut Pradopo (dalam Imerisna, 2013:16) Ikon adalah tanda hubungan antara penanda dan petandanya yang bersifat 
alamiah, contohnya potret orang menandai orang yang ada dipotret, gambar kuda menandai kuda yang nyata.

Pada kumpulan puisi Tersebab $A k u$ Melayu karya Taufik Ikram Jamil ada banyak aspek ikon yang dimunculkan oleh pengarang. Dari hasil analisis semiotik aspek ikon ini ke-14 puisi, terdapat data yang menunjukkan aspek ikon. Adapun judul-judul puisi tersebut yaitu Gurindam Bukit Siguntang, Hanya karena Aku bukan Orang Jawa: Biografi Dara Petak, Inilah Tabikku yang ditangkap Senyap, Tak Sempat Pulang ke Riau, Catatan Terakhir oleh Raffles, Di Sungai Siak, Kalau Roboh Kota Melaka, Jarak, Datang pada Setiap, Orang Asing Rupanya Aku, Menikah, Kita Akan Menjadi Kitab Bijak, Datang Lagi ke Bengkalis, Dari Sepi yang Bernama Putih. Penelitian semiotik aspek ikon ini terbukti dengan data yang ditemukan sebanyak 274 data. Dari puisi-puisi tersebut ditemukan ikon penggambaran langsung diri penulis, dimana banyak sekali penggunaan kata $a k u$ yang mengikonkan dirinya. Dalam kumpulan puisi ini TIJ sangat menggambarkan secara penuh amarah dan gejolak rindu terhaap lingkungan dan seseorang yang sangat sepesial dikehidupannya. Hal ini juga perkuat dengan pendapat (Mukhlis et al., 2020) bahwa pembaca bisa mengetahui maksud dari suatu teks dengan melihat latar yang digunakan dari puisi tersebut.

\section{Aspek Indeks}

Berdasarkan hasil penelitian yang telah dilakukan, maka indeks yaitu hubungan tanda dan petanda yang memiliki hubungan sebab akibat. Menurut Pradopo (2009:121) Indeks adalah tanda yang menunjukkan ada hubungan alamiah antara tanda dan petanda yang berhubungan sebab akibat antara penanda dan petandanya. Menurut Sobur (2003:42) Indeks adalah tanda yang menunjukkan adanya hubungan alamiah antara tanda dan petanda yang bersifat hubungan sebab akibat, atau tanda yang langsung mengacu pada kenyataan. Contoh yang paling jelas ialah asap sebagai tanda adanya api.

Pada kumpulan puisi Tersebab Aku Melayu karya Taufik Ikram Jamil ada banyak aspek ikon yang dimunculkan oleh pengarang. Dari hasil analisis semiotik aspek indeks ini terdapat 10 puisi dari 14 puisi yang menunjukkan puisis tersebut berada pada aspek indeks. Adapun judul-judul puisi tersebut yaitu Gurindam Bukit Siguntang, Hanya karena Aku bukan Orang Jawa: Biografi Dara Petak, Inilah Tabikku yang ditangkap Senyap, Tak Sempat Pulang ke Riau, Catatan Terakhir oleh Raffles, Kalau Roboh Kota Melaka, Jarak, Orang Asing Rupanya Aku, Menikah, Kita Akan Menjadi Kitab Bijak. Kemudian data yang tidak terdapat aspek indeks yaitu pada puisi Di Sungai Siak, Datang pada Setiap, Datang Lagi ke Bengkalis, dan Dari Sepi yang Bernama Putih. Penelitian semiotik aspek indeks ini terbukti dengan data yang ditemukan sebanyak 12 data. Dari data yang telah dipaparkan, penulis, penyair mengungkapkan kerinduannya terhadap kota bernama Riau, dimana kota tersebut banyak sekali melukiskan kenangan tentang kehidupannya dan juga kekasihnya yang tidak bisa dilupakan oleh sang penyair.

\section{Semiotik Aspek Simbol}

Simbol yaitu suatu bentuk yang menandai sesuatu yang lain di luar perwujudan bentuk simbol tertentu. Menurut Pradopo (2009:121) Simbol adalah tanda yang menunjukkan bahwa tidak ada hubungan alamiah antara penanda dan petandanya, hubungan bersifat arbitrer (Semaumaunya) hubungan berdasarkan konvensi (perjanjian) masyarakat. Istilah simbol juga dapat diartikan sebagai lambang yang mengacu kepada objek tertentu diluar lambang itu.

Pada kumpulan puisi Tersebab Aku Melayu karya Taufik Ikram Jamil ada banyak aspek ikon yang dimunculkan oleh pengarang. Dari hasil analisis semiotik aspek simbol ini terdapat 12 puisi dari 14 puisi yang menunjukkan puisis tersebut berada pada aspek simbol. Adapun juduljudul puisi tersebut yaitu Gurindam Bukit Siguntang, Hanya karena Aku bukan Orang Jawa: Biografi Dara Petak, Inilah Tabikku yang ditangkap Senyap, Tak Sempat Pulang ke Riau, Catatan Terakhir oleh Raffles, Di Sungai Siak, Kalau Roboh Kota Melaka, Jarak, Datang pada Setiap, Orang Asing Rupanya Aku, Menikah, dan Kita Akan Menjadi Kitab Bijak. Kemudian data yang tidak terdapat aspek simbol yaitu pada puisi Datang Lagi ke Bengkalis, dan Dari Sepi yang Bernama Putih. Penelitian semiotik aspek simbol ini terbukti dengan data yang ditemukan sebanyak 
28 data. Dari data yang telah dituliskan, penyair sangat banyak menceritakan gejolak kerinduan dan kesedihannya, penyair sangat mengenang semua kejadian yang ia lalui dan menyimbolkkan kejadian tersebut dalam berberapa kata yang ia sisipkan di puisi-puisinya.

\section{SIMPULAN}

Berdasarkan dari hasil penelitian ini, banyak penulis karya sastra terkhususnya penulis puisi pada masa ini menggunakan kata-kata atau kalimat yang menunjukkan keberadaan aspek ikon, indeks, dan simbol. Kajian semiotik yang menjadikan petanda sebagai makna yang ingin disampaikan penulis dalam puisi yang ditulisnya. Salah satunya penulis penemukan aspek-aspek kajian semiotik pada buku kumpulan puisi Tersebab Aku Melayu Karya Taufik Ikram Jamil.

Tabel 1. Ikon, indeks dan symbol Kumpulan Puisi Tersebab Aku Melayu Karya Taufik Ikram Jamil

\begin{tabular}{|c|l|l|}
\hline No & Aspek & Jumlah \\
\hline 1. & Ikon & 274 \\
\hline 2. & Indeks & 12 \\
\hline 3. & Simbol & 28 \\
\hline
\end{tabular}

Tabel di atas menjelaskan bahwa analisis semiotik ini penulis menemukan aspek ikon, indeks, dan simbol yang terdapat dalam kumpulan puisi Tersebab Aku Melayu karya Taufik Ikram Jamil. Pada penelitian ini penulis hanya memfokuskan penelitian pada 14 dari 59 puisi karya Taufik Ikram Jamil. Adapun jumlah aspek ikon adalah sebanyak 274 data, aspek indeks 12 data, dan aspek simbol terdapat 28 data. Aspek yang lebih dominan adalah aspek ikon dengan jumlah 274 data yang terdapat dalam 14 puisi Tersebab Aku Melayu karya Taufik Ikram Jamil. Berikut peneliti paparkan deskripsi sampel masing - masing hasil penelitian:

\section{REFERENSI}

A, T. (1984). Ilmu Sastra: Sastra dan Ilmu Sastra: Pengantar Teori Sastra. Jakarta: Dunia Pustaka Jaya.
Hoed, B. H. (2011). Semiotik dan Dinamika Sosial Budaya. Jakarta: Komunitas Bambu.

Imerisna. (2011). Analisis Semiotik Mantra Pengobatan Anak-Anak Masyyarakat Melayu Kenegaraan Kari. Pekanbaru: Universitas Riau.

Mukhlis, M., Masjid, A. Al, Widyaningrum, H. K., Komariah, K., \& Sumarlam, S. (2020). Analisis Wacana Kritis Model Teun A.Van Dijk pada Surat Kabar Online dengan Tajuk Kilas Balik Pembelajaran Jarak Jauh Akibat Pandemi Covid-19. Geram, 8(2).

Pardopo, R. D. (2009). Pengkajian Puisi. Yogyakarta: Gajah Mada Universitas Press.

Rahman, E., \& Jalil, A. (2004). Teori Kesusastraan. Pekanbaru: Unri Press.

Ratna, N. K. (2003). Teori, Metode dan Teknik Penelitian Sastra. Yogyakarta: Pustaka Pelajar.

Sobur, A. (2003). Semiotika Komunikasi. Bandung: PT. Remaja Rosdakarya.

Sukanda, M. (1993). Pembinaan Kritik Sastra Indonesia Masalah Sistematika Analisis Struktur Fiksi. Bandung: Angksa.

Sumardjo, J., \& Saini, K. (1997). Apresiasi Kesusastraan. Jakarta: Gramedia.

Supriadi, dkk. (2020). Makna Budaya dan Nilai Pendidikan Karakter dalam Syair Ikan Terubuk. GERAM, 8, 2.

Zaimar. (2008). Semotik dan Penerapannya Dalam Karya Sastra. Jakarta: Departemen Pendidikan Nasional. 